\title{
INTRA AND INTER-RATER RELIABILITY IN DYNAMIC VALGUS IN SOCCER PLAYERS
}

\author{
CONFIABILIDADE INTRA E INTERAVALIADOR NO VALGO DINÂMICO EM ATLETAS DE FUTEBOL
}

Diego Brenner Ribeiro' (ID

(Physiotherapist)

Gustavo de Mello Rodrigues² (iD

(Physiotherapist)

Dernival Bertoncello $0^{1,2,3}$ (1D

(Physiotherapist)

1. Universidade Federal do

Triângulo Mineiro (UFTM),

Postgraduate Program in

Physiotherapy, Uberaba, MG, Brazil

2. Universidade Federal Triângulo

Mineiro (UFTM), Postgraduate

Program in Physical Education,

Uberaba, MG, Brazil.

3. Human Movement Analysis Laboratory (LAMH), Department of Applied Physiotherapy, Universidade Federal do Triângulo Mineiro (UFTM), Uberaba, $M G$, Brazil.

\section{Correspondence:}

Dernival Bertoncello,

Universidade Federal do Triângulo Mineiro (UFTU), Departamento de Fisioterapia Aplicada, Instituto de Ciências da Saúde. Rua Vigário Carlos, 100, Sala 406, Abadia, Uberaba, MG, Brazil. 38025-350. dernival.bertoncello@uftm.edu.br

\begin{abstract}
Introduction: The two-dimensional (2D) methods of dynamic assessment of knee valgus are popular because of their low cost and the fact that they are easy to implement. It is believed that dynamic valgus of the knee is one of the main disorders responsible for non-contact lesions of the anterior cruciate ligament. There are two categories of reliability with regard to data collectors: inter-rater (reliability among multiple data collectors) and intra-rater (reliability of a single data collector). Objectives: To assess intra and inter-rater reliability during the step-down test in professional soccer athletes, using initial and final angles for each test repetition. Methods: The sample consisted of 29 professional soccer players. All study participants were considered by club physiotherapists to be free of any musculoskeletal injury and were performing daily training tasks. Two male evaluators participated in the study. Results: For each data group, mean and standard deviation were determined. The intra- and inter-rater reliability of all data was determined using the intraclass correlation coefficient (ICC), with a confidence interval of $95 \%$ and alpha of $p \leq 0.05$. Rater 1 was classified in the first intra-rater stage of the analysis for heel touch, with good to excellent reliability. For the inter-rater analysis, both for heel touch and for greater valgus angle, there was excellent reliability among the raters. Conclusion: It was concluded that there is high inter-rater and intra-rater reliability through two-dimensional analysis using the Step Down Test in professional soccer athletes. Level of evidence II; Development of diagnostic criteria in consecutive patients (with a "gold" reference standard applied).
\end{abstract}

Keywords: Stress test; Athletes; Knee joint; Athletic injuries.

\section{RESUMO}

Introdução: Os métodos bidimensionais (2D) de avaliação dinâmica de valgo de joelho são populares devido ao baixo custo e à grande facilidade de implementação. Acredita-se que o valgo dinâmico do joelho seja um dos principais responsáveis pelas lesões do ligamento cruzado anterior sem contato direto. Existem duas categorias de confiabilidade com relação aos coletores de dados: confiabilidade entre vários coletores, que é a confiabilidade interavaliador e a confiabilidade de um único coletor de dados, denominada confiabilidade intra-avaliador. Objetivos: Avaliar a confiabilidade intra e interavaliadores durante o Step Down Test em atletas profissionais de futebol, utilizando angulações iniciais e finais de cada repetição do teste. Métodos: A amostra foi composta por 29 jogadores de futebol profissional. Todos os participantes do estudo foram considerados livres de qualquer lesão musculoesquelética por fisioterapeutas do clube e estavam realizando tarefas diárias de treinamento. Dois avaliadores do sexo masculino participaram do estudo. Resultados: Para cada grupo de dados, a média e o desvio padrão foram determinados. A confiabilidade intra e interavaliadores de todos os dados foi determinada pelo coeficiente de correlação intraclasse (ICC), com intervalo de confiança de 95\% e alfa de $p \leq 0,05$. O avaliador 1 foi classificado no primeiro passo intra-avaliador da análise para toque do calcanhar com boa a excelente confiabilidade. Para análise interavaliadores, tanto para o toque do calcanhar quanto para maior ângulo valgo, houve excelente confiabilidade entre os avaliadores. Conclusão: Existe alta confiabilidade interavaliador e intra-avaliador por meio da análise bidimensional utilizando o Teste Step Down em atletas profissionais de futebol. Nível de evidência ll; Desenvolvimento de critérios diagnósticos em pacientes consecutivos (com padrão de referência "ouro" aplicado).

Descritores: Teste de esforço; Atletas; Articulação do joelho; Lesões em atletas.

\section{RESUMEN}

Introducción: Los métodos bidimensionales (2D) de evaluación dinámica de valgo de rodilla son populares debido al bajo costo y a la gran facilidad de implementación. Se cree que el valgo dinámico de rodilla sea uno de los principales responsables por las lesiones del ligamiento cruzado anterior sin contacto directo. Existen dos categorías de confiabilidad con relación a los colectores de datos: confiabilidad entre varios colectores, que es la confiablidad interevaluadory la confiabilidad de un único colector de datos, denominada confiabilidad intraevaluador. Objetivos: Evaluar la confiabilidad intra e interevaluadores durante el Step Down Testen atletas profesionales de fútbol, utilizando angulaciones iniciales y finales de cada repetición del test. Métodos: La amuestra fue compuesta por 29 jugadores de fútbol profesional. Todos los participantes del estudio fueron considerados libres de cualquier lesión musculoesquelética 
por fisioterapeutas del cluby estaban realizando tareas diarias de entrenamiento. Dos evaluadores de sexo masculino participaron del estudio. Resultados: Para cada grupo de datos, fueron determinados el promedio y la derivación estándar. La confiabilidad intra e interevaluadores de todos los datos fue determinada por el coeficiente de correlación intraclase (ICC), con intervalo de confianza de $95 \%$ y alfa de $p \leq 0,05$. El evaluador 1 fue clasificado en el primer paso interevaluador del análisis para toque del talón con buena a excelente confiabilidad. Para análisis interevaluadores tanto para o toque del talón como para mayor ángulo valgo, hubo excelente confiabilidad entre los evaluadores. Conclusión: Existe alta confiabilidad interevaluador e intraevaluador por medio del análisis bidimensional utilizando el Test Step Down en atletas profesionales de fútbol. Nivel de evidencia Il; Desarrollo de criterios diagnósticos en pacientes consecutivos (con estándar de referencia "oro" aplicado).

Descriptores: Test de esfuerzo; Atletas; Articulación de la rodilla; Lesiones en atletas.

\section{INTRODUCTION}

Two-dimensional (2D) methods of dynamic evaluation of the knee valgus are popular due to their low cost and easy implementation. The three-dimensional (3D) assessment of the dynamic knee valgus angle is considered the gold standard measurement strategy ${ }^{\prime}$; it considers the movement analysis and describes the relative relationship between the femur and the tibia. ${ }^{2,3}$

It is believed that the dynamic valgus of the knee is one of the main responsible for non-contact injuries of the anterior cruciate ligament (ACL). ${ }^{4}$ It results from the combination of movements of the femur and tibia, which can be influenced by the knee's proximal and distal joints, including the body, hip, and ankle regions.,5 Alterations in the knee alignment in dynamic movements, such as increased medial deviation, may contribute to the occurrence of disorders such as patellofemoral pain and ACL injury?

Reliability is an important component of researches, especially when it comes to simpler assessments that demand the evaluators' attention and insight. There are two categories of reliability: reliability between multiple data collectors, which is inter-evaluator reliability; and reliability of a single data collector, which is called intra-evaluator reliability. ${ }^{8}$

Previous studies have reported moderate to good reliability among evaluators for visual assessment of movement during a unipodal mini squats $(k=0.92)^{9}$ and step down in healthy subjects $(k=0.59)$, and in those with patellofemoral pain syndrome $(\mathrm{K}=0.67) .{ }^{10} \mathrm{It}$ is noteworthy that the step-down (SD) test is a functional task that requires descending a step, involves mechanical stress to support weight at various knee flexion angles, as well as dynamic muscle control. An alteration in mechanics during the SD test can cause abnormal stress on the knees in both the tibiofemoral and patellofemoral joints. ${ }^{11}$

Considering this, due to the importance of analyzing the relationship between knee angulation and other body regions, the objective of the study was to assess the intra and inter-evaluator reliability during the step-down test in professional soccer athletes, using initial and final angles for each test repetition.

\section{METHODOLOGY}

\section{Experimental Approach to the Problem}

This is a cross-sectional observational study. Pre-season evaluation was carried out in professional players from the Uberaba Sport Club, in the city of Uberaba / MG. In this evaluation, the step-down test was used to verify the quality of single leg squat movement. Before the test, standardized instructions for the performance of the test were provided for each subject in the sample. For inclusion in the study, the subjects should be between 18 and 30 years old, active in training and daily activities at the team, and without surgical interventions in the last 6 months. Athletes with injuries that left them out of activities for two weeks or more, in the hip, knee, and ankle joints were excluded.

\section{Participants}

The sample consisted of twenty-nine (29) professional soccer athletes from the Uberaba Sport Club team, in the city of Uberaba/MG, who were recruited and able to participate in the step-down test assessment in accordance to the inclusion criteria pre-established by the evaluators. They had an average age of $22.4 \pm 4.3$ years; $73.7 \pm 9.8 \mathrm{~kg}$; and $179.0 \pm 9.0 \mathrm{~cm}$ (Table 1). Four athletes were excluded from the study due to failure to complete the test (Figure 1).

All of them were considered free from any musculoskeletal injuries by the physical therapists of the team and were performing daily training tasks at the time of the study. This study was approved by the Human Research Ethics Committee of the Universidade Federal do Triângulo Mineiro, under opinion number 2347067/2017. The athletes were informed of the benefits and risks associated with participating in the study before signing the free consent form.

\section{Evaluators}

Two male evaluators participated in the study. Evaluator 1 has nine years of experience in orthopedic and sports evaluation and is part of the Postgraduation Program in Physical Therapy. Evaluator 2 has two years of experience in orthopedic and sports evaluation and is part of the Postgraduation Program in Physical Education at the Universidade Federal do Triângulo Mineiro. Each evaluator analyzed the videos separately, with a 14-day interval, to consider inter- and intra-evaluator reliability.

Table 1. Mean and standard deviation of the sample.

\begin{tabular}{c|c|c}
\hline \multicolumn{3}{c}{ Physical Characteristics of the Sample } \\
\hline Variables & Mean & Standard Deviation \\
\hline Age (years) & 22.40 & \pm 4.36 \\
\hline Body mass $(\mathrm{Kg})$ & 73.74 & \pm 9.88 \\
\hline Height $(\mathrm{cm})$ & 179.00 & \pm 0.09 \\
\hline
\end{tabular}

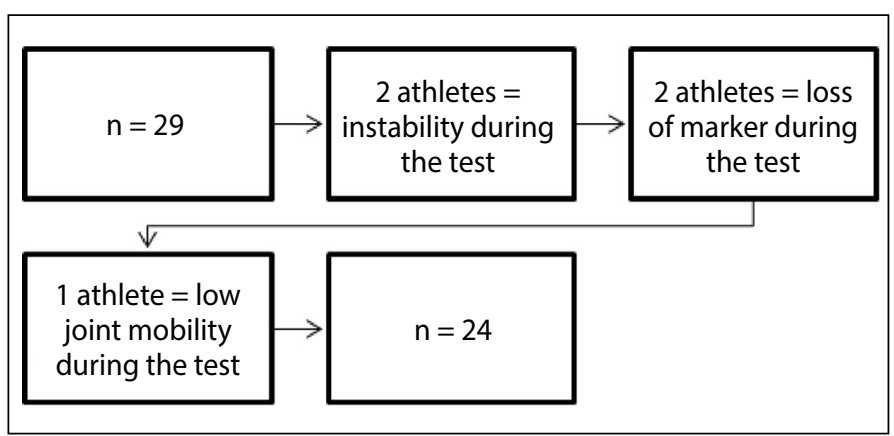

Figure 1. Flowchart of the sample. 


\section{Procedures}

During the evaluation of the step-down test, participants were filmed from a frontal plane. For video analysis, the Kinovea ${ }^{\circledR} 0.25$ program was used. The two evaluators of the study were assigned to complete the analysis of the angulations that were previously established: step 1 - video analysis when the athlete touches the heel on the ground during the test; step 2 - video analysis at the moment of the largest valgus angle during the test. The knee valgus was evaluated considering three leg points, the antero-superior iliac spine, the midpoint of the patella, and the anterior tibial tuberosity. For each stage, the athlete's angulation in the initial and final position of the test was evaluated, and each athlete performed 3 repetitions of the test on each side. For each angle obtained, the intra- and inter-evaluator reliability was verified. To perform the kinematic evaluation, reflective markers were placed on the most evident structures of the lower limbs of all athletes, the antero-superior iliac spine, greater trochanter of the bilateral femur, lateral and medial epicondyle of the femur, midpoint of the patella, tuberosity of the tibia, lateral and medial malleoli, and base of the third bilateral metatarsus. A Canon video camera was positioned at a distance of 3 meters from the athlete, on a tripod, $75 \mathrm{~cm}$ above ground. Only the frontal plane of the athletes was filmed during the 3 repetitions for each limb, since the objective was to verify deviations of adduction of the lower limb during the activity. ${ }^{12}$

\section{Step Down Test}

The test was performed on a $15 \mathrm{~cm}$ high, $30 \mathrm{~cm}$ wide, and $1 \mathrm{~m}$ long wood step. All athletes were instructed to climb the step, position themselves on the step, the third finger of the foot of the lower limb that was being evaluated positioned in a marking on the step. The contralateral limb remained outside the wood step, so the athletes were instructed to perform a squat with the hands positioned on the waist, above the iliac spines - so that the lower limb that was in motion had an extended knee and ankle dorsiflexion - l lowering the heel towards a mark made on the ground five $\mathrm{cm}$ in front of and next to the step. Three repetitions were performed on each side. ${ }^{12}$ All participants performed the evaluation and wore a bathing suit to allow the visualization of all the anatomical structures described above (Figure 2).

\section{Procedures for video analysis}

Only the frontal plane was filmed during the 3 repetitions during of the test, since the intention was to verify only the deviations of the

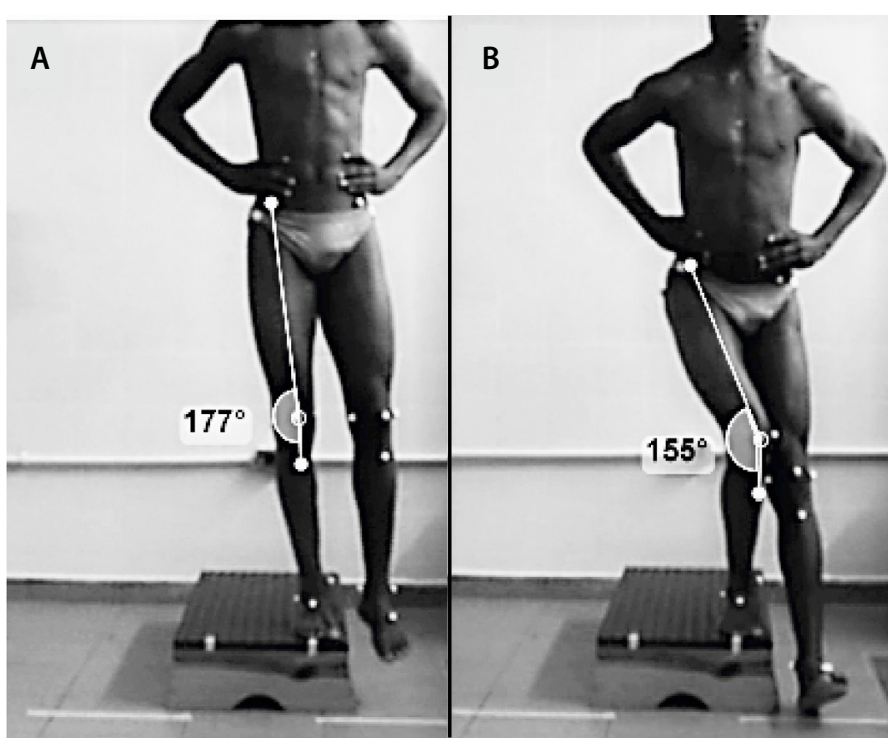

Figure 2. Step-down test, (a) starting position, (b) ending position. adduction of the lower limb during the activities, and because it is an adaptation for simple evaluation in this plan. After placing reflective markers, athletes were assessed individually. ${ }^{12}$ The footage was then edited to produce individual files for all 29 athletes, featuring each movement performed simultaneously on both members. These video files were then analyzed by the evaluators, who completed the video-based evaluation on two separated occasions. The evaluators had two weeks to evaluate all video files with a period of one week between repeated evaluations. The evaluators had three weeks to see the footage and analyze the angles. The intra- and inter-evaluator reliability were determined by comparing the analysis before and after two weeks, observing the initial and final position of each repetition, both for step 1 and for step 2 .

\section{Statistical analysis}

The mean and standard deviation of each data set were determined. Statistical analyzes were performed using the statistical software SPSS for Windows version 21.0 (IBM SPSS Inc., Chicago. IL USA). The intra- and inter-evaluator reliability of all data was determined using the intraclass correlation coefficient (ICC), with a 95\% confidence interval and an alpha of $p \leq 0.05 .{ }^{13}$ This choice was due to its ability to deal with cross-over design studies, using more than one evaluator, as was the case in this study. ${ }^{14}$ The simple ICC measurement was used to investigate whether the analysis in step 1 would match step 2 for each evaluator and between them.

\section{RESULTS}

For the Intra-evaluator reliability variable, the test considered the moments when the athlete touched the heel on the ground and when valgus was the larger during the test, whether in the eccentric or concentric stage of the movement. Therefore, the initial data from the first and final analysis of the test, for each evaluator, were compared with the second analysis of the video. As a result, intra-evaluator reliability ranged from 0.848 to 0.976 , showing a significant correlation for the evaluator $1(p<0.01)$ in the assessment of the heel touch in the initial and final positions of the test, for both right and left limbs (Table 2). In order to assess the largest valgus during the test, the first analysis was compared to the second, and intra-evaluator reliability ranged from 0.938 to 0.989 , with a significant correlation for evaluator $1(p<0.01)$ in the initial and final position of the test, for the right and left limbs.

In order to check the Intra-evaluator reliability for comparing the first analysis to the second analysis, a significant correlation for evaluator 2 ( $p<0.01$ ) was found, and reliability varied from 0.960 to 0.990 in the evaluation of the touch of the heel in the initial and final position of the test in the right and left limb. There was also a significant correlation for evaluator 2 ( $p<0.01$ ), with reliability ranging from 0.943 to 0.994 for evaluating the largest valgus of the initial and final position of the test, of the right and left limbs. (Table 3)

To assess inter-evaluator reliability, the analysis of video 1 and, later, the analysis of video 2 by both the evaluators, for both the touch of the heel and for the largest valgus during the test, were analyzed. For the heel touch in the first video analysis, a significant correlation $(p<0.01)$

Table 2. Intra-evaluator reliability for heel touch, Evaluator 1.

\begin{tabular}{|c|c|c|c|c|c|}
\hline \multicolumn{3}{|c|}{ Right side Initial and Final } & \multicolumn{3}{|c|}{ Left side Initial and Final } \\
\hline Repetitions & $\mathrm{CC}$ & $P$ & Repetitions & $\mathrm{CC}$ & $p$ \\
\hline 1a $\mathrm{Rl} 1 \times \mathrm{RI} 2$ & 0.848 & $0.01^{*}$ & $1^{\text {a }} \mathrm{RI} 1 \times \mathrm{RI} 2$ & 0.952 & $0.01^{*}$ \\
\hline $2^{\mathrm{a}} \mathrm{RI} 1 \times \mathrm{R} / 2$ & 0.967 & $0.01^{*}$ & $2^{\mathrm{a}} \mathrm{RI} 1 \times \mathrm{RI} 2$ & 0.936 & $0.01^{*}$ \\
\hline 3a RI1 x RI2 & 0.944 & $0.01^{*}$ & 3a RI1 x RI2 & 0.941 & $0.01^{*}$ \\
\hline 1a RF1 $\times$ RF2 & 0.926 & $0.01^{*}$ & 1a RF1 $\times$ RF2 & 0.976 & $0.01^{*}$ \\
\hline $2^{\mathrm{a}} \mathrm{RF} 1 \times \mathrm{RF} 2$ & 0.960 & $0.01^{*}$ & $2^{\mathrm{a}} \mathrm{RF} 1 \times \mathrm{RF} 2$ & 0.975 & $0.01^{*}$ \\
\hline 3a RF1 $\times$ RF2 & 0.967 & $0.01^{*}$ & 3a RF1 $\times$ RF2 & 0.973 & $0.01^{*}$ \\
\hline
\end{tabular}

RI1 = initial repetition first analysis; RI2 = initial repetition according to the second analysis; RF1 = final repetition first analysis; RF2 $=$ final repetition second analysis; $C C=$ correlation coefficient; ${ }^{*}=p<0.01$ 
between the evaluators was found, when comparing the initial and final measurements of the test, with reliability ranging from 0.903 to 0.971 . A significant result $(p<0.01)$ was also identified between the evaluators involving the largest valgus during the test, in the first analysis of the video, for the initial and final measurements of the test, with reliability ranging from 0.902 to 0.987 . (Table 4)

To compare the second analysis of the video, a significant result ( $p$ $<0.01$ ), with a reliability variance from 0.911 to 0.985 , was found between the evaluators with regards to the heel touch, for the initial and final measurements. Finally, the comparison between the evaluators for the second analysis of the video was analyzed, showing that there was a significant result $(p<0.01)$ regarding the moment of greatest valgus, with reliability ranging from 0.934 to 0.988 , for the initial and final measures. (Table 5)

Table 3. Intra-evaluator reliability for higher valgus during the test, Evaluator 2

\begin{tabular}{|c|c|c|c|c|c|}
\hline \multicolumn{3}{|c|}{ Right side Initial and Final } & \multicolumn{3}{|c|}{ Left side Initial and Final } \\
\hline Repetitions & $\mathrm{CC}$ & $p$ & Repetitions & $\mathrm{CC}$ & $p$ \\
\hline 1a $\mathrm{R} \mid 1 \times \mathrm{RI} 2$ & 0.969 & $0.01^{*}$ & 1a $\mathrm{RI} 1 \times \mathrm{RI} 2$ & 0.970 & $0.01^{*}$ \\
\hline $2^{a} \mathrm{R}|1 \times R| 2$ & 0.979 & $0.01^{*}$ & $2^{\mathrm{a}} \mathrm{RI} 1 \times \mathrm{RI} 2$ & 0.985 & $0.01^{*}$ \\
\hline 3a RI1 x RI2 & 0.948 & $0.01^{*}$ & 3a RI1 x RI2 & 0.981 & $0.01^{*}$ \\
\hline 1a RF1 $\times$ RF2 & 0.987 & $0.01^{*}$ & 1a RF1 $\times$ RF2 & 0.943 & $0.01^{*}$ \\
\hline 2a RF1 $\times$ RF2 & 0.979 & $0.01^{*}$ & 2a RF1 $\times$ RF2 & 0.992 & $0.01^{*}$ \\
\hline 3a RF1 $\times$ RF2 & 0.990 & $0.01^{*}$ & 3a RF1 x RF2 & 0.994 & $0.01^{*}$ \\
\hline
\end{tabular}

$\mathrm{R} 11=$ initial repetition first analysis: $\mathrm{RL} 2=$ initial repetition according to the second analysis. $\mathrm{RF} 1=$ final repetition first analysis; RF2 $=$ final repetition second analysis; $C C=$ correlation coefficient; ${ }^{*}=p<0.01$

Table 4. Inter-evaluator reliability for higher valgus. first stage.

\begin{tabular}{|c|c|c|c|c|c|}
\hline \multicolumn{3}{|c|}{ Right side Initial and Final } & \multicolumn{3}{|c|}{ Left side Initial and Final } \\
\hline Repetitions & $\mathrm{CC}$ & $p$ & Repetitions & $\mathrm{CC}$ & $p$ \\
\hline 1 a $\mathrm{RI} 1 \times \mathrm{RI} 2$ & 0.945 & $0.01^{*}$ & 1a $\mathrm{RI} 1 \times \mathrm{RI} 2$ & 0.969 & $0.01^{*}$ \\
\hline 2a RI1 x RI2 & 0.960 & $0.01^{*}$ & 2a RI1 x RI2 & 0.977 & $0.01^{*}$ \\
\hline 3a $\mathrm{Rl} 1 \times \mathrm{RI} 2$ & 0.902 & $0.01^{*}$ & 3a RI1 x RI2 & 0.957 & $0.01^{*}$ \\
\hline 1a RF1 x RF2 & 0.963 & $0.01^{*}$ & 1a RF1 $\times$ RF2 & 0.963 & $0.01^{*}$ \\
\hline $2^{\mathrm{a}} \mathrm{RF} 1 \times \mathrm{RF} 2$ & 0.976 & $0.01^{*}$ & $2^{\mathrm{a}} \mathrm{RF} 1 \times \mathrm{RF} 2$ & 0.969 & $0.01^{*}$ \\
\hline 3a RF1 x RF2 & 0.987 & $0.01 *$ & 3a RF1 $\times$ RF2 & 0.982 & $0.01^{*}$ \\
\hline
\end{tabular}

$\mathrm{RI} 1=$ initial repetition first analysis; $\mathrm{RI} 2=$ initial repetition according to the second analysis; $\mathrm{RF} 1=$ final repetition first analysis; RF2 = final repetition second analysis; $C C=$ correlation coefficient; ${ }^{*}=p<0.01$

Table 5. Inter-evaluator reliability for higher valgus, second stage.

\begin{tabular}{|c|c|c|c|c|c|}
\hline \multicolumn{3}{|c|}{ Right side Initial and Final } & \multicolumn{3}{|c|}{ Left side Initial and Final } \\
\hline Repetitions & $\mathrm{CC}$ & $p$ & Repetitions & $\mathrm{CC}$ & $p$ \\
\hline 1a $R|1 \times R| 2$ & 0.934 & $0.01^{*}$ & 1a $\mathrm{R}|1 \times \mathrm{R}| 2$ & 0.986 & $0.01^{*}$ \\
\hline $2^{\mathrm{a}} \mathrm{RI} 1 \times \mathrm{RI} 2$ & 0.975 & $0.01^{*}$ & $2^{\mathrm{a}} \mathrm{RI} 1 \times \mathrm{RI} 2$ & 0.973 & $0.01^{*}$ \\
\hline 3a RI1 x RI2 & 0.945 & $0.01^{*}$ & 3a RI1 x RI2 & 0.974 & $0.01^{*}$ \\
\hline 1a RF1 $\times$ RF2 & 0.981 & $0.01^{*}$ & 1a RF1 $\times$ RF2 & 0.941 & $0.01^{*}$ \\
\hline 2a RF1 $\times$ RF2 & 0.988 & $0.01^{*}$ & 2a RF1 $\times$ RF2 & 0.986 & $0.01^{*}$ \\
\hline 3a RF1 x RF2 & 0.987 & $0.01^{*}$ & 3a RF1 x RF2 & 0.986 & $0.01^{*}$ \\
\hline
\end{tabular}

first analysis; RF2 = final repetition second analysis; $C C=$ correlation coefficient; ${ }^{*}=p<0.01$

\section{DISCUSSION}

The objective of the study was to evaluate the intra and inter-evaluator reliability during the step-down Test in professional soccer athletes, with analysis of the initial and final position after observing the heel touch and the largest knee valgus. The results show that the step-down test has high intra- and inter-evaluator reliability when the evaluation is carried out through video analyses in professional soccer athletes, and especially if the evaluators are experienced and trained in the field.
The evaluations carried out in this study were made through 2D analysis, which shows the importance of having simple and low-cost equipment that can bring reliable results in the sports field. Paz et al. $(2017)^{15}$, in their study with volleyball athletes, showed that 3D movement analysis is not practical for most clinical or field environments, where athletic performance is often assessed, due to the financial cost, the spatial and time demands of an analysis laboratory. The same authors say that techniques that use 2D analysis with simple, portable, and inexpensive equipment, can be much more useful in these situations. Comparing 3D and 2D analysis, Schurr et al. (2017) ${ }^{16}$ identified in their study a strong correlation between the two systems of analysis for hip and knee in the sagittal plane, allowing a more robust assessment of the consistency between the measures, providing agreement and linear association.

This study shows, in the analysis of evaluator 1, a good and high intra-evaluator reliability result, that varied between 0.848 to 0.976 . In a study that assessed intra- and inter-evaluator reliability in 2D analyses of single-leg squats viewed from a frontal plane in athletics individuals, Harris-Hayes et al. (2014) $)^{17}$ observed that the reliability values ranged from 0.80 to 0.90 for intra-evaluator reliability and from 0.75 to 0.90 for inter-evaluator reliability, indicating a substantial to excellent reliability. For the authors, the standardized criteria used during visual assessments to determine the classifications of movement patterns of the lower limbs require minimal training. Thus, it would be feasible to use visual assessment to identify and treat musculoskeletal disorders related to movement, and large studies to assess the association between lower limb movement patterns and musculoskeletal injury, if they were already present. The results found are similar to those of the aforementioned authors, when considering that the evaluators had a 2-hour training in video analysis, and a session to refresh their knowledge about the procedures and variables to be considered during the evaluations.

With regards to inter-evaluator reliability and heel touch in step 1, this study showed high reliability, ranging from 0.903 to 0.971 , and when analyzing step 2, it showed a result ranging from 0.911 to 0.985 . Studies by Rabin and Kozol (2010) (10) and Piva et al. (2006) ${ }^{18}$, showed that the inter-evaluator reliability of the step-down test was reported to be moderate $(k=0.59-0.67)$. Rabin et al. $(2014)^{19}$ evaluated the step-down test in male and female soldiers diagnosed with patellofemoral pain and found an inter-evaluator reliability of 0.94 , indicating a high coefficient.

Another point to consider is the number of days to perform the analyses. This study's evaluators used a mean of 14 days interval for the inter and intra-evaluations, in different cities, without communication between them. Ekegren et al. (2009) ${ }^{20}$, used a 14-day interval to reevaluate the test videos in order to reduce the probability that the evaluators would remember their initial considerations. Dingenen et al. $(2013)^{21}$ also used video analysis in elite athletes to assess inter- and intra-evaluator reliability, with a 7-day interval between assessments.

\section{ACKNOWLEDGEMENTS}

This work was carried out with the support of the Coordenação de Aperfeiçoamento de Pessoal de Nível Superior (CAPES), Código de Financiamento [Funding Code] 001. Master's Degree Scholarships funded by the Conselho Nacional de Desenvolvimento Científico e Tecnológico (CNPq) and the Programa de Bolsas de Iniciação Científica e Fundação de Amparo à Pesquisa do Estado de Minas Gerais (FAPEMIG).

All authors declare no potential conflict of interest related to this article

AUTHORS' CONTRIBUTIONS: Each author made significant individual contributions to this manuscript. DBR: elaboration of the entire research project, data collection, data analysis, writing, statistical analysis, revision; GMR: elaboration of the entire research project, data collection, data analysis, statistical analysis; DB: data analysis, statistical analysis, intellectual concept, writing and revision. All authors reviewed and approved the final version of the manuscript. 


\section{REFERENCES}

1. Willson JD, Ireland ML, Davis I. Core strength and lower extremity alignment during single leg squats. Med Sci Sports Exerc. 2006;38(5):945-52

2. Munro A, Herrington L, Carolan M. Reliability of 2-dimensional video assessment of frontal-plane dynamic knee valgus during common athletic screening tasks. J Sport Rehabil. 2012;21(1):7-11.

3. Myer GD, Ford KR, Hewett TE. New method to identify athletes at high risk of ACL injury using clinic-based measurements and freeware computer analysis. Br J Sports Med. 2011;45(4):238-44.

4. Hewett TE, Myer GD, Ford KR, Heidt RSJ, Colosimo AJ, McLean SG, et al. Biomechanical measures of neuromuscular control and valgus loading of the knee predict anterior cruciate ligament injury risk in female athletes: a prospective study. Am J Sports Med. 2005;33(4):492-501.

5. McLean SG, Lipfert SW, van den Bogert AJ. Effect of gender and defensive opponent on the biomechanics of sidestep cutting. Med Sci Sports Exerc. 2004;36(6):1008-16.

6. Dempsey AR, Lloyd DG, Elliott BC, Steele JR, Munro BJ, Russo KA. The effect of technique change on knee loads during sidestep cutting. Med Sci Sports Exerc. 2007;39(10):1765-73.

7. Powers $C M$. The influence of abnormal hip mechanics on knee injury: a biomechanical perspective. $J$ Orthop Sports Phys Ther. 2010;40(2):42-51.

8. McHugh ML. Interrater reliability: the kappa statistic. Biochem Med (Zagreb). 2012;22(3):276-82

9. Ageberg E, Bennell KL, Hunt MA, Simic M, Roos EM, Creaby MW. Validity and inter-rater reliability of mediolateral knee motion observed during a single-limb mini squat. BMC Musculoskelet Disord. 2010;11:265

10. Rabin A, Kozol Z. Measures of range of motion and strength among healthy women with differing quality of lower extremity movement during the lateral step-down test. J Orthop Sports Phys Ther. 2010;40(12):792-800.

11. Loudon JK, Wiesner D, Goist-Foley HL, Asjes C, Loudon KL. Intrarater reliability of functional performance tests for subjects with patellofemoral pain syndrome. J Athl Train. 2002;37(3):256-61.

12. Rabin A, Portnoy S, Kozol Z. The Association Between Visual Assessment of Quality of Movement and Three-Dimensional Analysis of Pelvis, Hip, and Knee Kinematics During a Lateral Step Down Test. J Strength Cond Res. 2016;30(11):3204-11.

13. Haitz K, Shultz R, Hodgins M, Matheson GO. Test-retest and inter-rater reliability of the functional lowe extremity evaluation. J Orthop Sports Phys Ther. 2014;44(12):947-54.

14. Bruton A, Conway JH, Holgate ST. Reliability: what isitand how is it measured? Physiotherapy. 2000;86(2):94-9.

15. Paz GA, Maia MF, Santana HG, Miranda H, Lima V, Wilson JD. Knee frontal plane projection angle: a comparison study between drop vertical jump and step-down tests with young volleyball athletes. J Sport Rehabil. 2019;28(2):153-8.

16. Schurr SA, Marshall AN, Resch JE, Saliba SA. Two-dimensional vídeo analysis is comparable to 3D motion capture in lower extremity movement assessment. Int J Sports Phys Ther. 2017;12(2):163-72

17. Harris-Hayes M, Steger-May K, Koh C, Royer NK, Graci V, Salsich GB. Classification of lower extremity movement patterns based on visual assessment: reliability and correlation with 2-dimensional video analysis. J Athl Train. 2014;49(3):304-10.

18. Piva SR, Fitzgerald K, Irrgang JJ, Jones S, Hando BR, Browder DA, et al. Reliability of measures of impairments associated with patellofemoral pain syndrome. BMC Musculoskelet Disord. 2006;7:33.

19. Rabin A, Kozol Z, Moran U, Efergan A, Geffen Y, Finestone AS. Factors Associated With Visually Assessed Quality of Movement During a Lateral Step-down Test Among Individuals With Patellofemoral Pain. J Orthop Sports Phys Ther. 2014;44(12):937-46

20. Ekegren CL, Miller WC, Celebrini RG, Eng JJ, Macintyre DL. Reliability and validity of observational risk screening in evaluating dynamic knee valgus. J Orthop Sports Phys Ther. 2009;39(9):665-74

21. Dingenen B, Malfait B, Vanrenterghem J, Verschueren SM, Staes FF. The reliability and validity of the measurement of lateral trunk motion in two-dimensional video analysis during unipodal functional screening tests in elite female athletes. Phys Ther Sport. 2014;15(2):117-23. 